ISSN 1392-3196 / e-ISSN 2335-8947

Zemdirbyste-Agriculture, vol. 102, No. 1 (2015), p. 87-94

DOI 10.13080/z-a.2015.102.011

\title{
Comparison of genetic diversity of three Impatiens species from Central Europe and Baltic region
}

\author{
Eugenija KUPCINSKIENE, Lina ZYBARTAITE, Algimantas PAULAUSKAS \\ Vytautas Magnus University \\ Vileikos 8, Kaunas, Lithuania \\ E-mail: e.kupcinskiene@gmail.com
}

\begin{abstract}
The present study is aimed at evaluation of genetic diversity of populations of three Impatiens species from two countries by employing multilocus markers of two different types. The total number of individuals was 355 , the number of populations for each species - native Impatiens noli-tangere and invasive - I. parviflora, I. glandulifera, was 8 ( 4 from Lithuania and 4 from the Czech Republic). Impatiens species were evaluated according to 8 randomly amplified polymorphic DNA (RAPD) loci and 5 inter-simple sequence repeat (ISSR) loci. Independently of the site, at the species level polymorphism was the highest for I. glandulifera at RAPD loci $(35.2 \%$, as a mean per population) and for I. noli-tangere at ISSR loci (48\%). RAPD and ISSR based dendrograms for individuals and populations also principal coordinate analyses clearly clustered populations of each species according to their countries, except for ISSR based dendrogram for the populations of I. noli-tangere. Estimated at ISSR loci, molecular variance among the populations of the two countries was much smaller for native I. noli-tangere (7.3\%), when compared to invasive I. parviflora $(49.7 \%)$ or I. glandulifera $(45.6 \%)$. Genetic differentiation among the populations was the smallest for I. noli-tangere $\left(\mathrm{G}_{\mathrm{ST}}=0.36\right)$. The populations of both invasive species from the Czech Republic were more polymorphic at ISSR loci, when compared to those from Lithuania. Mantel test showed significant correlations between geographic and genetic distances in the case of both DNA markers. The Czech Republic's populations were bigger in size, grew in higher altitudes, mean annual temperatures of the site were higher by several degrees and mean annual rainfall was lower compared to Lithuania's. Polymorphisms at RAPD and ISSR loci might play different role for viability of populations of Impatiens species. ISSR markers were more useful for the assessment of genetic differences between native and invasive Impatiens species.
\end{abstract}

Key words: alien species, Balsaminaceae, diversity, invasions, marker.

\section{Introduction}

Throughout four decades expanding concern about environment problems has highlighted plant invasion process among the most evident adverse effects of human activities (Hulme, Barrett, 2013). Alien species on the way of their expansion might meet congenerous species. Few investigations deal with comparisons of geographically close relatives, local and alien ones like in the cases of genera Atriplex (Mandak, 2003) and Medicago (Vyšniauskienė et al., 2013).

Europe's Impatiens represent a unique opportunity to study invasion process due to very special set of the species: the first one - Impatiens noli-tangere, growing naturally, the second one $-I$. parviflora, widely spread alien with a very high degree of naturalization, and the third one - I. glandulifera, alien very actively spreading nowadays. Comprehensive research has been carried out explaining biology of separate Impatiens species (Coombe, 1956; Beerling, Perrins, 1993; Hatcher, 2003), and with each year this information is still increasing (Csiszar, Bartha, 2008; Chmura, 2014). During the previous century little information was collected concerning comparative biology of representatives of these genera. For three species of Impatiens distinctive early stages of development (Skálová et al., 2011), differences in allelopathic activities (Vrchotova et al., 2011), and in concentration of secondary compounds (Sera et al., 2005) were documented.

Despite moderate specifics in habitats (Ellenberg et al., 1992), there are cases when balsams are growing at small distances or besides, I. noli-tangere and especially I. parviflora (Chmura, 2014). Comparisons made in these circumstances allow elimination of major climate-related variations of the compared species. The topic concerning the assessment of genetic differences among I. nolitangere, I. parviflora and I. glandulifera has not received equal attention. With rare exceptions (Hatcher et al., 2004; Nagy, Korpelainen, 2014) most investigations deal with populations of one species growing in one country. Despite a rather long history of application of molecular markers for diversity analyses, comparisons of two or three Impatiens species are still missing.

Ecological analyses are usually wide-scope and to carry out them, prices should be reasonable. Multilocus dominant markers, like RAPD or ISSR meet such requirements and have been employed alone or together for the research of invaders of the other 
genera: Erigeron annuus (Edwards et al., 2006), Bunias orientalis (Patamsytè et al., 2013 b) and Medicago sativa (Vyšniauskienè et al., 2013). The present study is aimed at evaluation of populations of three Impatiens species from two countries employing two multilocus markers of different type. The objectives were to find out 1) the most polymorphic Impatiens species in each site, 2) to evaluate the relations between genetic and geographical distances of populations and 3) to compare the value of the used markers in revealing genetic differences between native and alien species of Impatiens.

\section{Materials and methods}

Plant material and sampling sites. Three Balsaminaceae species were investigated: Impatiens noli-tangere $\mathrm{L}$. as a native to most of Europe, and I. parviflora DC. and I. glandulifera Royle as invasive plants. To represent Eastern Baltic region and Central Europe, plant material was collected in Lithuania and the Czech Republic in August, 2012. Selection of sites was based on the availability of three Impatiens species, growing in the vicinity of each other. The populations were titled according to abbreviated geographic names of the studied sites (Skálová et al., 2011; 2013; Kupcinskiene et al., 2013); climate data were obtained from the meteorological stations situated closest to the sampling sites (Table 1). Molecular and genetic analyses were carried out at the Department of Biology, Vytautas Magnus University, Lithuania.

For the most contrasting populations according to the altitude, latitude $(\mathrm{N})$ and longitude $(\mathrm{E})$ the ranges were $40-470 \mathrm{~m}, 49^{\circ} 08^{\prime}$ and $55^{\circ} 30^{\prime}(\mathrm{N}), 13^{\circ} 53^{\prime}$ and $24^{\circ} 44^{\prime}$ (E), respectively. In comparison with Lithuania, for the populations in the Czech Republic the mean annual temperature was 1-3 degrees (C) higher and the mean annual rainfall was $258-353 \mathrm{~mm}$ lower. For the three Impatiens species the total number of individuals examined was 355 and the total number of populations was 24 . The distances between the sites fit into the range of $72-1046 \mathrm{~km}$.

Table 1. Geographic position and climate parameters of the populations of Impatiens noli-tangere, I. parviflora and I. glandulifera in Lithuania and the Czech Republic

\begin{tabular}{cccccccc}
\hline Country & $\begin{array}{c}\text { Location of } \\
\text { population }\end{array}$ & Notation & $\begin{array}{c}\text { Latitude } \\
\mathrm{N}\end{array}$ & $\begin{array}{c}\text { Longitude } \\
\mathrm{E}\end{array}$ & $\begin{array}{c}\text { Altitude } \\
\mathrm{m}\end{array}$ & $\begin{array}{c}\text { Annual mean } \\
\mathrm{T}^{\circ} \mathrm{C}\end{array}$ & $\begin{array}{c}\text { Annual } \\
\text { rainfall } \\
\mathrm{mm}\end{array}$ \\
\hline \multirow{5}{*}{ Lithuania } & Anykščiai & Any & $55^{\circ} 29^{\prime}$ & $25^{\circ} 30^{\prime}$ & 100 & 6.3 & 847 \\
& Varèna & Var & $56^{\circ} 20^{\prime}$ & $23^{\circ} 13^{\prime}$ & 64 & 6.5 & 833 \\
& Kaunas & Kau & $54^{\circ} 53^{\prime}$ & $23^{\circ} 49^{\prime}$ & 55 & 6.5 & 847 \\
& Juodkranté & Juo & $55^{\circ} 33^{\prime}$ & $21^{\circ} 07^{\prime}$ & 40 & 6.8 & 928 \\
\hline \multirow{3}{*}{ Czech } & Potštejn & Pot & $50^{\circ} 07^{\prime}$ & $16^{\circ} 32^{\prime}$ & 320 & 7.5 & 750 \\
Republic & Polabí & Pol & $50^{\circ} 12^{\prime}$ & $15^{\circ} 15^{\prime}$ & 190 & 9.5 & 575 \\
& Čelina & Cel & $49^{\circ} 73^{\prime}$ & $14^{\circ} 34^{\prime}$ & 290 & 8.5 & 575 \\
& Černětice & Vol & $49^{\circ} 14^{\prime}$ & $13^{\circ} 89^{\prime}$ & 470 & 7.5 & 600 \\
\hline
\end{tabular}

DNA extraction, RAPD (randomly amplified polymorphic DNA) and ISSR (inter-simple sequence repeat) analyses. The total DNA (deoxyribonucleic acid) was extracted by a genomic DNA purification kit \#KO512 (Thermo Scientific, Lithuania). For the next steps the concentration of DNA of each specimen was adjusted to approximately $20 \mathrm{ng} \mu \mathrm{l}^{-1}$. Eight 10-mer primers (Metabion International AG, Germany) were employed for RAPD analysis (Table 2). Polymerase chain reactions (PCR) were performed as described earlier (Kupcinskiene et al., 2013).

For ISSR analyses five primers (Metabion International $\mathrm{AG}$ ) were used and PCR was carried out following Provan et al. (2007).

Statistical analysis. On the basis of the presence (1) or absence $(0)$ of the amplification products at each RAPD and ISSR loci, data sheet was constructed. Percentage of polymorphic loci, Nei's genetic diversity (h) and Shannon's information index (I), genetic differentiation among populations $\left(\mathrm{G}_{\mathrm{ST}}\right)$ and $\mathrm{G}_{\mathrm{ST}}$-derived gene flow between populations were calculated as described earlier (Kupcinskiene et al., 2013). Molecular variance was compared between regions, between populations within region and within populations using AMOVA, Arlequin, version 3.1 (Excoffier, Lischer,
Table 2. Primers used to analyse populations of three Impatiens species at RAPD and ISSR loci

\begin{tabular}{ccc}
\hline DNA loci type & Primer & $\begin{array}{c}\text { Sequence of the primer } \\
5, \rightarrow 3\end{array}$ \\
\hline RAPD & OPA-20 & GTTGCGATCC \\
& OPD-20 & ACCCGGTCAC \\
& 222 & AAGCCTCCCC \\
& 250 & CGACAGTCCC \\
& 269 & CCAGTTCGCC \\
& 340 & GAGAGGCACC \\
& 474 & AGGCGGGAAC \\
& 516 & AGCGCCGACG \\
ISSR & ISSR2 & GGCC(AC) $)_{8}$ \\
& ISSR3 & CCGG(AG) 8 \\
& ISSR4 & CCGG(AC) $)_{8}$ \\
ISSR5 & GCGC(AG) $)_{8}$ \\
ISSR6 & GCGC(AC) ${ }_{8}$ \\
\hline
\end{tabular}

2010). Populations were compared by cluster analysis using an unweighted pair group method with arithmetic mean (UPGMA) based on Nei's genetic distances (GD), using PopGene, version 1.32 (Nei, 1978). Nei and Li's (1979) genetic distances among individuals were used to group individuals of populations, and dendrograms were drawn using TREECON, version 1.3 (Van de Peer, 
De Wachter, 1994). Populations were classified by the principal coordinate analysis using PCoA, GenAlEx, version 6.5 (Peakall, Smouse, 2012). Population Nei's genetic and geographic distances were related by Mantel test using GenAlEx, version 6.5.

\section{Results and discussion}

General parameters of the fragments at $R A P D$ and ISSR loci of Impatiens species and intrapopulation genetic diversity. Eight RAPD primers and three ISSR (ISSR2, ISSR3 and ISSR5) primers were useful for analysis of DNA polymorphism in the three examined species of Impatiens genera. In total, 362 and 209 fragments were generated by RAPD and ISSR primers, respectively. The primer ISSR4 was not applicable for I. noli-tangere and I. parviflora, the primer ISSR6 did not generate DNA fragments for I. glandulifera. Mean values of the number of DNA fragments generated per RAPD and ISSR loci were 45 and 42, respectively; intervals for separate markers were $33-56$ and $23-55$. At the species level the mean number of polymorphic RAPD loci per population was smaller for I. noli-tangere (31.8), I. parviflora (38.1) and higher for I. glandulifera (56.8). The same parameter for ISSR loci differed little between the studied species $(45,41.1$ and 40.5 , respectively). At the species level the mean of percentage of polymorphic RAPD loci per population was $13.9 \%$ for I. noli-tangere, $17.3 \%$ for I. parviflora and $26.5 \%$ for I. glandulifera, and at ISSR loci it was $48 \%$ for I. noli-tangere, $26.5 \%$ for I. parviflora and $22 \%$ for I. glandulifera (Table 3 ). Between the populations of the two countries very similar percentage of polymorphic RAPD loci was for I. nolitangere; values of this parameter were much higher for invasive Impatiens species, growing in Lithuania when compared to the ones growing in the Czech Republic. At ISSR loci the situation was the opposite: polymorphism was much higher for all three species of Impatiens from the Czech Republic. The differences between species according to the Nei's genetic diversity and Shannon's information index resembled those defined as percentage of polymorphic loci.

Table 3. Intrapopulation parameters of genetic diversity at RAPD and ISSR loci of Lithuania's and the Czech Republic's populations of three Impatiens species

\begin{tabular}{|c|c|c|c|c|c|c|}
\hline \multirow{2}{*}{ Notation } & \multicolumn{3}{|c|}{ RAPD loci } & \multicolumn{3}{|c|}{ ISSR loci } \\
\hline & $\% P$ & $h$ & $I$ & $\% P$ & $h$ & $I$ \\
\hline \multicolumn{7}{|c|}{ I. noli-tangere } \\
\hline Any & 16.2 & $0.062 \pm 0.149^{*}$ & $0.091 \pm 0.215$ & 27.9 & $0.083 \pm 0.159$ & $0.128 \pm 0.231$ \\
\hline Var & 11.8 & $0.049 \pm 0.141$ & $0.070 \pm 0.200$ & 29.7 & $0.074 \pm 0.136$ & $0.119 \pm 0.206$ \\
\hline $\mathrm{Kau}$ & 13.1 & $0.054 \pm 0.147$ & $0.079 \pm 0.208$ & 27.0 & $0.079 \pm 0.149$ & $0.123 \pm 0.221$ \\
\hline Juo & 11.4 & $0.048 \pm 0.139$ & $0.070 \pm 0.198$ & 27.9 & $0.098 \pm 0.171$ & $0.148 \pm 0.249$ \\
\hline Mean & 13.1 & 0.053 & 0.078 & 28.2 & 0.084 & 0.130 \\
\hline Pot & 14 & $0.054 \pm 0.140$ & $0.079 \pm 0.203$ & 64.9 & $0.156 \pm 0.157$ & $0.253 \pm 0.232$ \\
\hline Pol & 15.3 & $0.052 \pm 0.134$ & $0.079 \pm 0.196$ & 63.1 & $0.139 \pm 0.149$ & $0.229 \pm 0.221$ \\
\hline Cel & 12.2 & $0.041 \pm 0.116$ & $0.063 \pm 0.173$ & 73.0 & $0.187 \pm 0.169$ & $0.298 \pm 0.241$ \\
\hline Vol & 17 & $0.069 \pm 0.159$ & $0.101 \pm 0.228$ & 70.3 & $0.180 \pm 0.173$ & $0.286 \pm 0.246$ \\
\hline Mean & 14.6 & 0.054 & 0.081 & 67.8 & 0.166 & 0.267 \\
\hline \multicolumn{7}{|c|}{ I. parviflora } \\
\hline Any & 25.5 & $0.094 \pm 0.173$ & $0.139 \pm 0.250$ & 10.16 & $0.033 \pm 0.111$ & $0.050 \pm 0.161$ \\
\hline Var & 25.0 & $0.081 \pm 0.161$ & $0.122 \pm 0.233$ & 20.31 & $0.063 \pm 0.138$ & $0.098 \pm 0.206$ \\
\hline $\mathrm{Kau}$ & 22.7 & $0.078 \pm 0.160$ & $0.116 \pm 0.231$ & 10.94 & $0.029 \pm 0.097$ & $0.047 \pm 0.146$ \\
\hline Juo & 31.8 & $0.088 \pm 0.161$ & $0.135 \pm 0.233$ & 11.72 & $0.037 \pm 0.110$ & $0.056 \pm 0.165$ \\
\hline Mean & 26.3 & 0.085 & 0.128 & 13.3 & 0.041 & 0.063 \\
\hline Pot & 8.2 & $0.022 \pm 0.083$ & $0.036 \pm 0.127$ & 52.3 & $0.139 \pm 0.172$ & $0.219 \pm 0.250$ \\
\hline Pol & 8.2 & $0.022 \pm 0.083$ & $0.035 \pm 0.126$ & 37.5 & $0.100 \pm 0.159$ & $0.157 \pm 0.234$ \\
\hline $\mathrm{Cel}$ & 9.6 & $0.029 \pm 0.096$ & $0.045 \pm 0.145$ & 37.5 & $0.104 \pm 0.159$ & $0.163 \pm 0.237$ \\
\hline Vol & 7.3 & $0.017 \pm 0.067$ & $0.029 \pm 0.107$ & 31.25 & $0.093 \pm 0.155$ & $0.145 \pm 0.232$ \\
\hline Mean & 8.3 & 0.023 & 0.036 & 39.6 & 0.109 & 0.171 \\
\hline \multicolumn{7}{|c|}{ I. glandulifera } \\
\hline Any & 45.5 & $0.137 \pm 0.181$ & $0.211 \pm 0.262$ & 12.0 & $0.041 \pm 0.115$ & $0.063 \pm 0.174$ \\
\hline Var & 38.9 & $0.115 \pm 0.170$ & $0.177 \pm 0.249$ & 19.6 & $0.066 \pm 0.144$ & $0.100 \pm 0.213$ \\
\hline $\mathrm{Kau}$ & 38.9 & $0.112 \pm 0.164$ & $0.175 \pm 0.244$ & 16.3 & $0.058 \pm 0.138$ & $0.088 \pm 0.205$ \\
\hline Juo & 43.4 & $0.128 \pm 0.172$ & $0.198 \pm 0.253$ & 13.0 & $0.041 \pm 0.114$ & $0.064 \pm 0.172$ \\
\hline Mean & 41.7 & 0.123 & 0.190 & 15.2 & 0.052 & 0.079 \\
\hline Pot & 23.2 & $0.074 \pm 0.151$ & $0.113 \pm 0.221$ & 34.8 & $0.112 \pm 0.168$ & $0.172 \pm 0.250$ \\
\hline Pol & 34.9 & $0.104 \pm 0.162$ & $0.161 \pm 0.240$ & 22.8 & $0.078 \pm 0.152$ & $0.119 \pm 0.227$ \\
\hline $\mathrm{Cel}$ & 30.3 & $0.093 \pm 0.157$ & $0.144 \pm 0.233$ & 32.6 & $0.107 \pm 0.172$ & $0.163 \pm 0.252$ \\
\hline Vol & 26.3 & $0.080 \pm 0.150$ & $0.124 \pm 0.223$ & 25.0 & $0.082 \pm 0.151$ & $0.126 \pm 0.227$ \\
\hline Mean & 28.7 & 0.088 & 0.136 & 28.8 & 0.095 & 0.145 \\
\hline
\end{tabular}

* - mean \pm standard deviation, $\mathrm{n}=15 ; \% P$ - percentage of polymorphic DNA loci, $h$ - Nei's genetic diversity, $I-$ Shannon's information index; mean values per population \pm standard deviation 
Interpopulation genetic diversity of three Impatiens species. Minimum and maximum genetic distances between populations were of similar range for each Impatiens species at both RAPD (0.081-0.405 for I. noli-tangere, 0.129-0.460 for I. parviflora and 0.0810.460 for I. glandulifera) and ISSR loci (0.031-0.388 for I. parviflora and 0.092-0.499 for I. glandulifera). An exception was nearly twice lower range differences for I. noli-tangere at ISSR loci (0.037-0.180). Nei's genetic distances defined by ISSR and RAPD markers were related significantly for populations of all species: medium correlation was found for I. noli-tangere $(r=0.439, p<0.019)$, strong correlation was observed in the case of I. parviflora $(r=0.726, p<0.001)$ and I. glandulifera $(r=0.819, p<0.001)$.

Within ach out of the three species Nei's genetic distances calculated on the basis of RAPD loci were used to generate UPGMA dendrograms that clustered populations into two groups according to the countries (Fig. 1). The same was true for the invasive species dendrograms, based on ISSR loci, although populations of I. noli-tangere did not split into two groups according to the geographical origin. Clustering of individuals correctly allocated plants to the certain populations, no identical individuals were observed. Dendrograms for individuals of populations (these data are not shown in figures) of each species demonstrated similar relationships based on RAPD or ISSR loci: for invasive species, individuals

RAPD loci

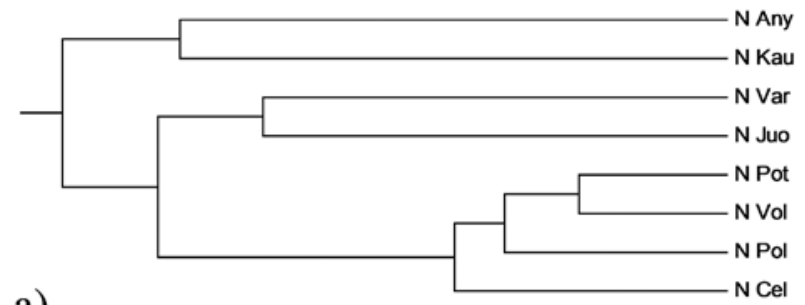

a)
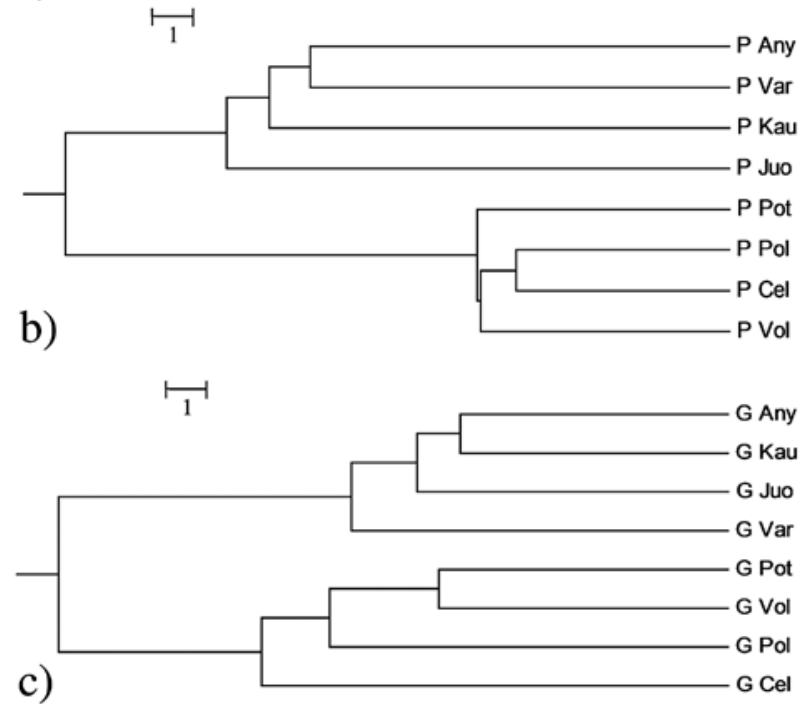

were split into two clades according to the country of origin. For I. noli-tangere one main cluster contained individuals of two populations from one country and the other cluster consisted of six populations, which were further subdivided into two subclades corresponding to countries. A similar clustering pattern was obtained using both RAPD and ISSR data.

The first three principal coordinates explained $69.4 \%$ and $74.6 \%$ of population variance respectively at RAPD and ISSR loci for I. noli-tangere; corresponding numbers for I. parviflora were $71.5 \%$ and $84.3 \%$, and for I. glandulifera $67.1 \%$ and $77.7 \%$. The $1^{\text {st }}$ vs $2^{\text {nd }}$ axes of principal coordinates separated the populations into two parts according to the country of origin. Such pattern of grouping was observed for all three species using both RAPD and ISSR data (Fig. 2). Similar view was obtained for the $1^{\text {st }} v s 3^{\text {rd }}$ axis plots. An exception to all these cases was ISSR-based plots of populations of $I$. noli-tangere, for subdivision of these populations according to the country of origin main axis were $2^{\text {nd }} v s 1^{\text {st }}$ or $2^{\text {nd }} v s 3^{\text {rd }}$.

In the cases of two different types of loci of three Impatiens species, significant molecular variance was documented between regions (in our study countries were assumed as the regions), among populations within countries and within populations (Table 4).

Molecular variance of RAPD loci between the countries was big enough and quite similar for all three species of Impatiens. Molecular variance within
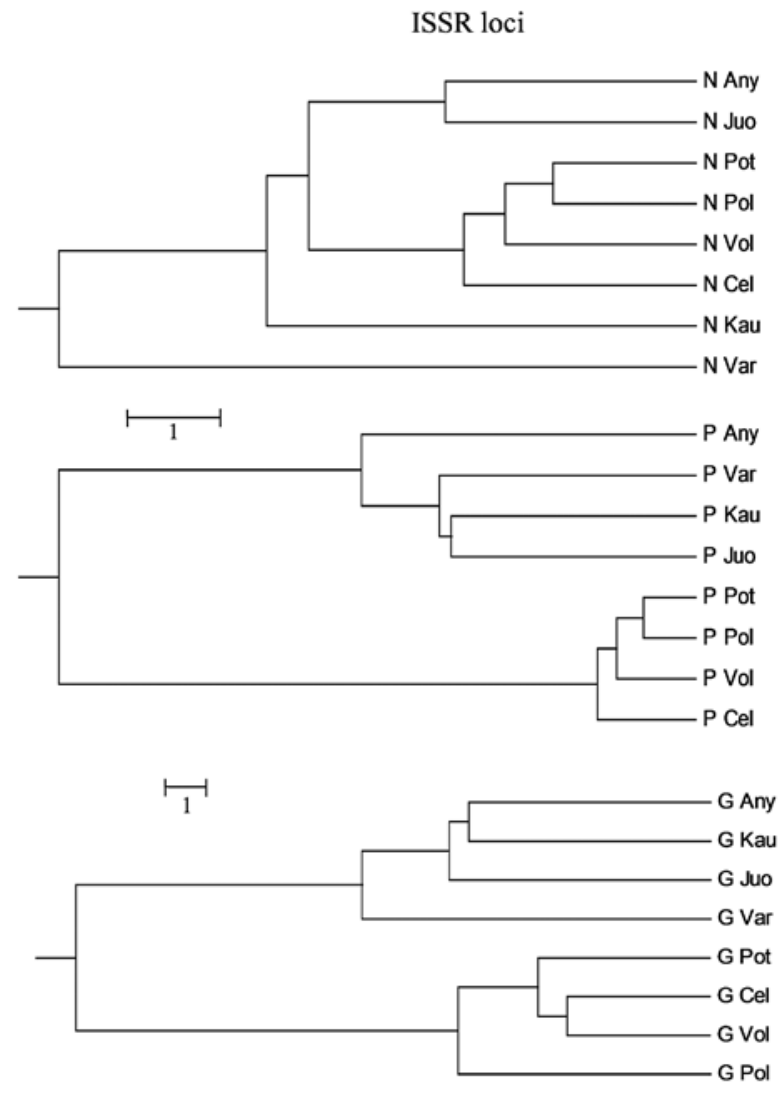

Notes. UPGMA dendrograms are based on Nei's (1978) genetic distances estimated on the basis of RAPD and ISSR loci. The title of each population comprises species name $(\mathrm{N}-$ I. noli-tangere, $\mathrm{P}-$ I. parviflora, $\mathrm{G}-$ I. glandulifera) + notation (explanations of abbreviations in Table 1).

Figure 1. Relationships of populations for each out of three Impatiens species 
RAPD loci
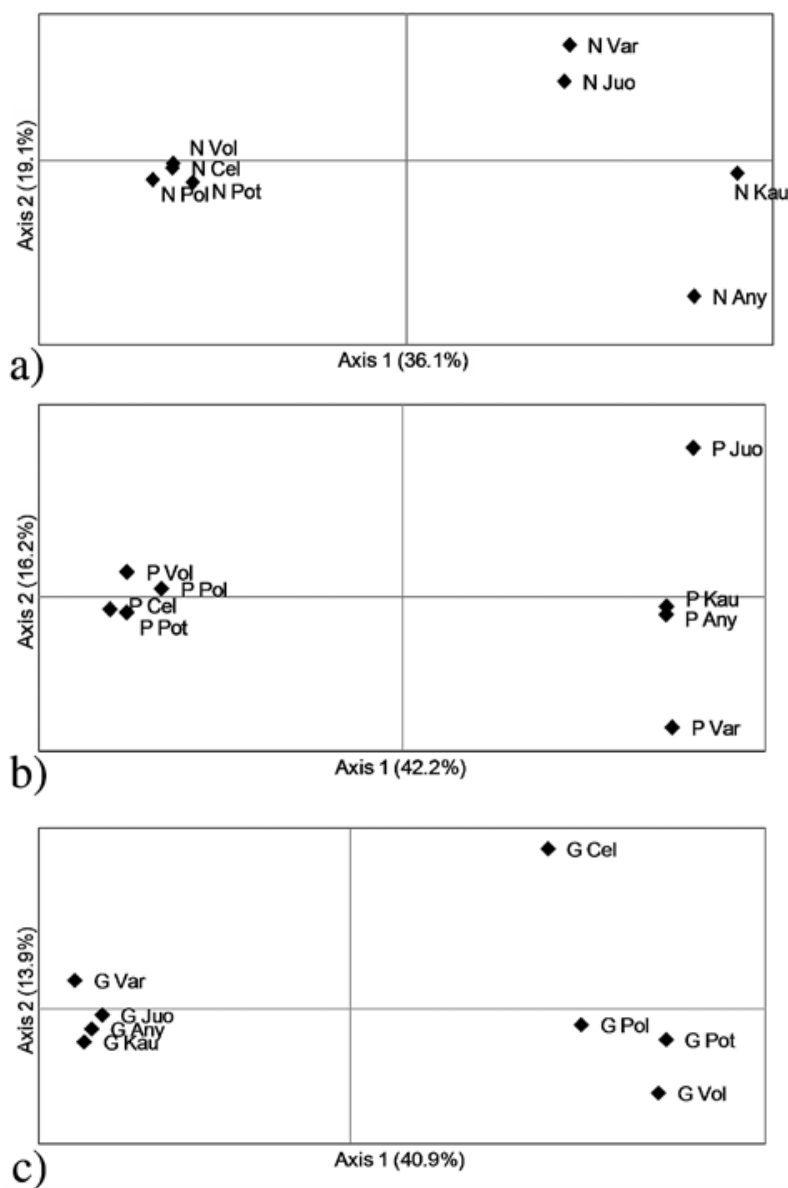

ISSR loci
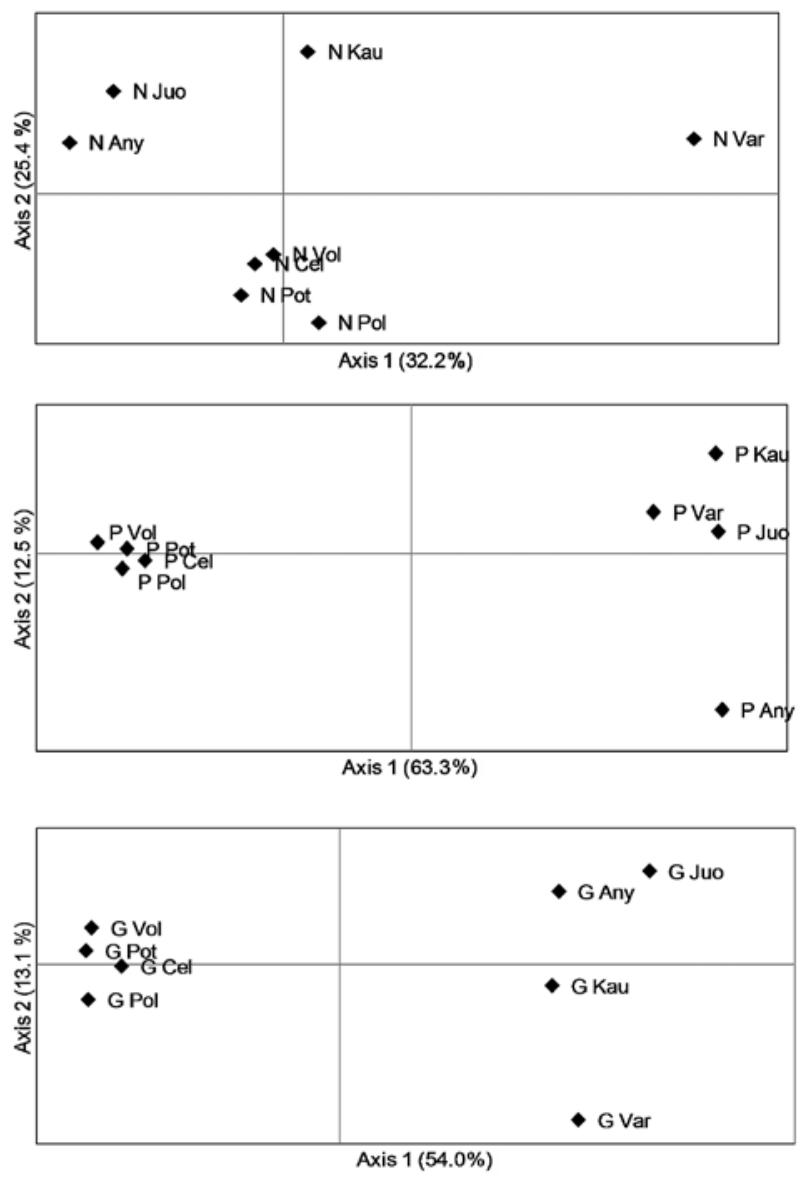

$\mathrm{N}$ - I. noli-tangere, $\mathrm{P}-$ I. parviflora, $\mathrm{G}-$ I. glandulifera + notation (explanations of abbreviations in Table 1)

Figure 2. Principal coordinate analyses of Lithuania's and the Czech Republic's populations of three Impatiens species at RAPD and ISSR loci

Table 4. Molecular variance (AMOVA) between regions (Eastern Baltic region, Lithuania and Central Europe region, Czech Republic), among populations within regions and within populations of Impatiens species

\begin{tabular}{|c|c|c|c|c|c|c|c|c|}
\hline \multirow{2}{*}{$\begin{array}{c}\text { DNA loci } \\
\text { Source } \\
\end{array}$} & \multicolumn{4}{|c|}{ RAPD } & \multicolumn{4}{|c|}{ ISSR } \\
\hline & df & SS & $\mathrm{VC}$ & $\%$ & df & SS & $\mathrm{VC}$ & $\%$ \\
\hline & \multicolumn{8}{|c|}{ I. noli-tangere } \\
\hline Between regions & 1 & 1064.1 & 12.6 & $30.03 *$ & 1 & 144.2 & 1.1 & $7.25^{*}$ \\
\hline Among populations within regions & 6 & 2010.7 & 23.0 & $54.63 * *$ & 6 & 471.5 & 4.8 & $31.06^{* *}$ \\
\hline Within populations & 107 & 689.5 & 6.4 & $15.34 * *$ & 107 & 1024.2 & 9.6 & $61.69 * *$ \\
\hline \multirow[t]{2}{*}{ Total } & 114 & 3764.3 & 42.0 & & 114 & 1639.9 & 15.1 & \\
\hline & \multicolumn{8}{|c|}{ I. parviflora } \\
\hline Between regions & 1 & 1285.8 & 16.0 & $36.36^{*}$ & 1 & 838.5 & 12.3 & $49.69^{*}$ \\
\hline Among populations within regions & 6 & 1970.1 & 21.5 & $48.89 * *$ & 6 & 596.1 & 6.2 & $25.03 * *$ \\
\hline Within populations & 112 & 724.9 & 6.5 & $14.75 * *$ & 112 & 702.0 & 6.3 & $25.28 * *$ \\
\hline \multirow[t]{2}{*}{ Total } & 119 & 3980.8 & 43.9 & & 119 & 2136.7 & 24.8 & \\
\hline & \multicolumn{8}{|c|}{ I. glandulifera } \\
\hline Between regions & 1 & 853.1 & 10.4 & $27.45^{*}$ & 1 & 632.7 & 8.9 & $45.56^{*}$ \\
\hline Among populations within regions & 6 & 1374.3 & 14.4 & $38.00 * *$ & 6 & 583.8 & 6.2 & $31.59 * *$ \\
\hline Within populations & 112 & 1466.3 & 13.1 & $34.55 * *$ & 112 & 501.2 & 4.5 & $22.85 * *$ \\
\hline Total & 119 & 3693.7 & 37.9 & & 119 & 1717.6 & 19.6 & \\
\hline
\end{tabular}

Note. Significant levels are based on 1000 permutations; df - degree of freedom, SS - sum of squares, VC - variance components; ** $-P \leq 0.01, *-P \leq 0.05$.

populations was very low for I. noli-tangere and I. parviflora. Genetic differentiation among populations $\left(\mathrm{G}_{\mathrm{ST}}\right)$ was very high and gene flow $\left(\mathrm{N}_{\mathrm{m}}\right)$ was low for all species at RAPD loci (respectively 0.79 and 0.13 for I. noli-tangere, 0.81 and 0.12 for I. parviflora, 0.61 and 0.32 for I. glandulifera). Similar view of genetic diversity 
partitioning was obtained for invasive species comparing $\mathrm{G}_{\mathrm{ST}}$ and $\mathrm{N}_{\mathrm{m}}$ at ISSR loci (0.68 and 0.23 for I. parviflora, 0.73 and 0.18 for I. glandulifera, respectively). Genetic differentiation at ISSR loci was nearly twice lower for native Impatiens $\left(\mathrm{G}_{\mathrm{ST}}=0.36\right)$.

Mantel test showed significant $(p<0.05)$ correlations between population geographic and genetic distances. These correlations were stronger for invasive species (for I. parviflora $r=0.861$ at RAPD loci and $r=0.941$ at ISSR loci, for I. glandulifera $r=0.893$ and $r=875$, respectively) and weaker for $I$. noli-tangere ( $r=0.696$ at RAPD loci and $r=0.249$ at ISSR loci). Significant correlations between genetic and geographic distances at RAPD and ISSR loci were found in other studies of invasive species of the other genera, like Erigeron annuus (Edwards et al., 2006; Patamsytė et al., 2013 a), although insignificant in a case of Medicago sativa, M. falcata (Vyšniauskienė et al., 2013) and Bunias orientalis (Patamsytè et al., 2013 b). Comparisons of genetically close invasive and native plants are of special importance for elucidating mechanisms of spread and forecasting this process (Hejda et al., 2009), prompting theoretically validated methods for eradication. In our study, the populations of three different Impatiens species in the same site, independently of the site, in all cases showed the highest polymorphism at RAPD loci for I. glandulifera. For Czech populations it was observed that the abundances of I. noli-tangere and I. parviflora were negatively affected by that of I. glandulifera, which was shown to overtop the shorter congeners from the seedling stage under moist conditions (Skálová et al., 2013).

In all sites $I$. noli-tangere was the most polymorphic species according to ISSR data. It prompts that multilocus DNA markers could be helpful in quantifying Impatiens differences at the species level: influence of environment factors (climate and soil characteristics) between sites were smothered by the species-specific traits. Sets of two types of multilocus markers allowed distinguishing herbaceous species of other genera like Trifolium (Dabkevičienè et al., 2011) or Medicago (Vyšniauskienè et al., 2013). At the species level the mean values of intrapopulation diversity (firstly percentage of polymorphic loci) for I. parviflora at RAPD loci were more similar to those of I. noli-tangere $(13.9 \%$ and $17.3 \%$, respectively). These $I$. noli-tangere and I. parviflora similarities at RAPD loci are in agreement to indicatory values of habitats (Ellenberg et al., 1992), which are the same for both species according to light conditions, and soil fertility also climate continentally. Intervention of I. parviflora to the forests of Europe and growth besides I. noli-tangere is well known in many countries (Hejda et al., 2009; Kupcinskiene et al., 2013; Chmura, 2014). When compared to Czech Republic's populations, more polymorphic RAPD loci of Lithuania's (the Baltic Sea region) populations of I. glandulifera are in agreement with ocean proximity indicating value $-2^{\text {nd }}$ class among 9 classes (Ellenberg et al., 1992). Indicatory values of the habitats are defined in Central Europe and primarily addressed to this region. The first settlement of I. glandulifera in Europe is documented for Great Britain, and flourishing of the species in this country up to the present time is a well-known fact (Beerling, Perrins, 1993; Chittka, Schurkens, 2001). Indicatory values of the ocean/continent proximity (and maybe other factors) might be totally different if defined in the native areal of I. glandulifera.
Comparison of habitats of three European Impatiens species shows that there is gradient of the most extreme altitudes known for the native areals of these species: I. glandulifera is growing in the most extreme altitudes: up to $4000 \mathrm{~m}$ in the Himalayan mountains, while extremes for I. parviflora are lower, reaching only $2500 \mathrm{~m}$ in Turkestan and for I. noli-tangere $2000 \mathrm{~m}$ altitudes are documented as the highest (Coombe, 1956; Beerling, Perrins; 1993; Hatcher, 2003). In invasive range I. glandulifera is growing in much lower altitudes and even plains 40-1500 m (Beerling, Perrins, 1993). This means that $I$. glandulifera has found a favourite climate shelter in Europe when compared to harsh climate of the Himalays. Based on such assumptions it might be needed to revise species indicatory values addressing them separately for native and invasive areals. The other assumption is that higher polymorphism at RAPD loci for I. glandulifera populations is evidence of still ongoing active process of invasion and these adaptations of the species are not finished yet. For example, in the early stages of development differences in sensitivity to frosts were observed among Czech Republic's populations of I. glandulifera (Skálová et al., 2011).

Three Impatiens species differ in phenology (Kuusk et al., 1996; Hatcher, 2003). Long history of native species in their own areal might provide opportunities for adjusting to the local climate scenarios. In the light of it, higher percentage of polymorphic ISSR loci for populations of $I$. noli-tangere $(48 \%)$ when compared to respective values of I. parviflora and I. glandulifera $(26.5 \%$ and $22 \%)$ might reflect climate adjustment preferences between native and alien species. I. nolitangere flowers earlier and disappears in the autumn early enough before frosts, while I. glandulifera germinates the first and dies the last. No one indicatory value (Ellenberg's indicatory values are represented by means) coincides between I. parviflora and I. glandulifera, although in some cases they are growing besides (Beerling, Perrins; 1993; Skálová et al., 2011; Kupcinskiene et al., 2013). Invasion-related processes could be influenced by very similar mean values of intrapopulation characteristics at ISSR loci for I. parviflora and I. glandulifera.

According to our study, population geographic distances correlated with genetic distances in greater extent for invasive Impatiens species, when compared to the native one. It might show that populations of I. nolitangere are spread in more homogenic habitats and habitats of invasive Impatiens are more diverse. Till now at least two very different types of habitats are characteristic of these aggressive aliens: of anthropogenic origin and semi-natural. The history of Impatiens invasion, lasting for two centuries, started in the sites of anthropogenic origin from which two alien species escaped/expanded areas, occupying more natural although different habitats - I. glandulifera spread along less shaded river banks (Chittka, Schurkens, 2001; Hejda et al., 2009) and I. parviflora turned to the forest occupying more shaded habitats (Chmura, 2014). Exact data about invasion routes of Impatiens within continental Europe are not available. Herbarium specimens were collected earlier in Central Europe (Csiszar, Bartha, 2008) when compared to Eastern Baltic region (Natkevičaitè-Ivanauskienè, 1951). Where and at what time routes of alien Impatiens species split to the Czech Republic and Lithuania are still the questions that need to be addressed in the future investigation. 
In the present study only a small number of populations of three Impatiens species from two European countries were examined, and further more comprehensive research (in terms of individuals, populations and especially markers) is required to validate and extend the existing data. Although very often continent-wide areas encompass net of populations which are differently interrelated to one other in terms of numerous influencing factors of natural and anthropogenic origin and resulting from molecular studies view is briefly entitled under "multiple introductions" or the other general phrases.

\section{Conclusions}

1. Comparison of the populations of the three species growing in each collection site, in all cases showed the highest polymorphism of randomly amplified polymorphic DNA (RAPD) loci for Impatiens glandulifera, and I. noli-tangere in all sites was the most polymorphic species at ISSR loci.

2. RAPD and inter-simple sequence repeat (ISSR) based unweighted pair group method with arithmetic mean (UPGMA) cluster analysis of populations and axis of principal coordinates plots clearly subdivided the populations according to the country of origin for all three Impatiens species (an exception was ISSR based dendrogram for I. noli-tangere): different climate, altitude and other geography-related conditions might have importance for polymorphism of RAPD and ISSR loci of invasive in Europe Impatiens species.

3. Our analyses show that for the distinction between native and invasive Impatiens species more important might be DNA regions related to simple sequence repeats.

\section{Acknowledgments}

This study was funded by the Research Council of Lithuania, grant No. LEK-07/2012. We are grateful to RNDr. Hana Skálová and prof. RNDr. Petr Pyšek for the plant material from the Czech Republic and data about geographical location, climate.

Received 27112014 Accepted 13022015

\section{References}

Beerling D. J., Perrins J. M. 1993. Biological flora of British Isles: Impatiens glandulifera Royle (Impatiens roylei Walp.). Journal of Ecology, 81 (2): 367-382 http://dx.doi.org/10.2307/2261507

Chittka L., Schurkens S. 2001. Successful invasion of a floral market. Nature, 411: 653-653 http://dx.doi.org/10.1038/35079676

Chmura D. 2014. Biology and ecology of an invasion of Impatiens parviflora DC in natural and semi-natural habitats. Bialsko-Biala, Poland, $216 \mathrm{p}$.

Coombe D. E. 1956. Biological flora of the British Isles, Impatiens parviflora DC. Journal of Ecology, 44 (2): 701-713 http://dx.doi.org/10.2307/2256857

Csiszar A., Bartha D. 2008. Small balsam (Impatiens parviflora DC.). Botta-Dukat Z., Balogh L. (eds). The most important invasive plants in Hungary. Vacratot, Hungary, p. 139-149

Dabkevičienè G., Paplauskienė V., Vilčinskas E. 2011. Assessment of genetic diversity in Trifolium spp. using
ISSR and RAPD markers. Journal of Food, Agriculture and Environment, 9 (1): 210-214

Edwards P. J., Frey D., Bailer H., Baltisberger M. 2006. Genetic variation in native and invasive populations of Erigeron annuus as assessed by RAPD markers. International Journal of Plant Sciences, 167 (1): 93-101 http://dx.doi.org/10.1086/498729

Ellenberg H., Ruprecht D., Volkmar W., Willy W., Dirk P. 1992. Zeigerwerte von Pflanzen in Mitteleuropa. Scripta Geobotanica, 18: 1-258 (in German)

Excoffier L., Lischer H. E. L. 2010. Arlequin suite ver 3.5: a new series of programs to perform population genetics analyses under Linux and Windows. Molecular Ecology Resources, 10 (3): 564-567 http://dx.doi.org/10.1111/j.1755-0998.2010.02847.x

Hatcher P. E. 2003. Biological flora of the British Isles, Impatiens noli-tangere L. Journal of Ecology, 91 (1): 147-167 http://dx.doi.org/10.1046/j.1365-2745.2003.00741.x

Hatcher P. E., Wilkinson M. J., Albani M. C., Hebbern C. A. 2004. Conserving marginal populations of the foodplant (Impatiens noli-tangere) of an endangered moth (Eustroma reticulatum) in a changing climate. Biological Conservation, 116 (3): 305-317 http://dx.doi.org/10.1016/S0006-3207(03)00200-3

Hejda M., Pyšek P., Jarošik V. 2009. Impact of invasive plants on the species richness, diversity and composition of invaded communities. Journal of Ecology, 97 (3): 393-403 http://dx.doi.org/10.1111/j.1365-2745.2009.01480.x

Hulme P. E., Barrett S. C. H. 2013. Integrating trait- and nichebased approaches to assess contemporary evolution in alien plant species. Journal of Ecology, 101 (1): 68-77 http://dx.doi.org/10.1111/1365-2745.12009

Kupcinskiene E., Zybartaite L., Janulioniene R., Zukauskiene J., Paulauskas A. 2013. Molecular diversity of small balsam populations in relation to site characteristics. Central European Journal of Biology, 8 (10): 1048-1061 http://dx.doi.org/10.2478/s11535-013-0228-3

Kuusk V., Plotniece M., Jankeviciene R. 1996. Balsaminaceae A. Rich. Kuusk V. et al. (eds). Flora of the Baltic countries. II. Tartu, Estonia, $177 \mathrm{p}$.

Mandak B. 2003. Germination requirements of invasive and non-invasive Atriplex species: a comparative study. Flora, 198 (1): 45-54 http://dx.doi.org/10.1078/0367-2530-00075

Nagy A. M., Korpelainen H. 2014. Population genetics of Himalayan balsam (Impatiens glandulifera): comparison of native and introduced populations. Plant Ecology and Diversity http://dx.doi.org/10.1080/17550874.2013.863407

Natkevičaitė-Ivanauskienè M. 1951. Adventive flora of Lithuanian Soviet Republic. Proceedings of Institute of Biology, 1: 77-124 (in Lithuanian)

Nei M. 1978. Estimation of average heterozygosity and genetic distance from a small number of individuals. Genetics, 89 (3): $583-590$

Nei M., Li W. H. 1979. Mathematical model for studying genetic variation in terms of restriction endonucleases. Proceedings National Academy Sciences USA, 76 (10): 5269-5273 http://dx.doi.org/10.1073/pnas.76.10.5269

Patamsytė J., Rančelis V., Cèsnienė T., Kleizaitè V., Tunaitienè V., Naugžemys D., Vaitkūnienè V., Žvingila D. 2013 (a). Clonal structure and reduced diversity of the invasive alien plant Erigeron annuus in Lithuania. Central European Journal of Biology, 8 (9): 898-911 http://dx.doi.org/10.2478/s11535-013-0206-9

Patamsytè J., Ċesnienè T., Naugžemys D., Kleizaitè V., Tunaitienė V., Vaitkūnienė V., Rančelis V., Mikaliūnaitė R., Žvingila D. 2013 (b). Different habitats show similar genetic structure of Bunias orientalis L. (Brassicaceae) in Lithuania. Notulae Botanicae Horti Agrobotanici ClujNapoca, 41 (2): 396-403 
Peakall R., Smouse P. E. 2012. GenAlEx 6.5: genetic analysis in Excel. Population genetic software for teaching and research - an update. Bioinformatics, 28: 2537-2539 http://dx.doi.org/10.1093/bioinformatics/bts460

Provan J., Love H. M., Maggs C. A. 2007. Development of microsatellites for the invasive riparian plant Impatiens glandulifera (Himalayan balsam) using inter simple sequence repeat cloning. Molecular Ecology Notes, 7: 451-453 http://dx.doi.org/10.1111/j.1471-8286.2006.01614.x

Sera B., Vrchotova N., Triska J. 2005. Phenolic compounds in the leaves of alien and native Impatiens plants. Alford D. V., Backhaus G. F. (eds). Plant protection and plant health in Europe: introduction and spread of invasive species. British Crop Production Council, p. 281-282

Skálová H., Moravcová L., Pyšek P. 2011. Germination dynamics and seedling frost resistance of invasive and native Impatiens species reflect local climatic conditions. Perspectives in Plant Ecology, Evolution and Systematics, 13 (3): $173-180$

http://dx.doi.org/10.1016/j.ppees.2011.03.005
Skálová H., Jarošik V, Dvoračková S., Pyšek P. 2013. Effect of intra- and interspecific competition on the performance of native and invasive species of Impatiens under varying levels of shade and moisture. PLoS One, 8 (5): e62842 http://dx.doi.org/10.1371/journal.pone.0062842

Van de Peer Y., De Wachter R. 1994. TREECON for Windows: a software package for the construction and drawing of evolutionary trees for the Microsoft Windows environment. Computer Applications in the Biosciences, 10 (5): 569-570

Vrchotova N., Sera B., Krejcova J. 2011. Allelopathic activity of extracts from Impatiens species. Plant, Soil and Environment, 57 (2): 57-60

Vyšniauskienė R., Rančelienė V., Patamsytė J., Žvingila D. 2013. High genetic differentiation among wild populations of alien Medicago sativa in Lithuania. Central European Journal of Biology, 8 (5): 480-491 http://dx.doi.org/10.2478/s11535-013-0159-4

ISSN 1392-3196 / e-ISSN 2335-8947

Zemdirbyste-Agriculture, vol. 102, No. 1 (2015), p. 87-94

DOI 10.13080/z-a.2015.102.011

\title{
Trijų sprigès (Impatiens) rūšių populiacijų genetinẻ įvairovė Centrinëje Europoje ir Baltijos regione
}

\author{
E. Kupčinskienė, L. Zybartaitè, A. Paulauskas \\ Vytauto Didžiojo universitetas
}

\section{Santrauka}

Tyrimo tikslas - ịvertinti trijų rūšių sprigių iš dviejų šalių populiacijų genetinę ịvairovę, taikant dviejų tipų molekulinius žymeklius. Natūraliai augančios paprastosios (Impatiens noli-tangere) ir invazinių rūšiu smulkiažiedès (Impatiens parviflora) ir bitinès (Impatiens glandulifera) - sprigès kiekvienos rūšies ištirta po 8 populiacijas (po 4 iš Lietuvos ir 4 iš Čekijos Respublikos), iš viso analizuoti 355 individai. Panaudoti 8 atsitiktinai pagausintos polimorfinès DNR (APPD) ir 5 paprastųų kartotinių sekų intarpų (PKSI) žymekliai. Nepriklausomai nuo šalies ar augimo vietos, rūšies lygmenyje didžiausiu polimorfizmu pagal APPD žymeklius išsiskyrè I. glandulifera (35,2 \%), pagal PKSI žymeklius - I. noli-tangere (48 \%). Abiejų žymeklių duomenimis, individų bei populiacijų dendrogramose ir taikant principinių koordinačių analizę kiekvienos rūšies populiacijos sudare atskirus lietuviškus ir čekiškus klasterius. PKSI žymeklių pagrindu sudarytoje dendrogramoje pagal šalis nepasiskirstė tik I. noli-tangere populiacijos. Panaudojus PKSI žymeklius, molekulinè genetinè įvairovè tarp šalių I. noli-tangere populiacijų buvo daug mažesnè $(7,3 \%)$ nei I. parviflora $(49,7 \%)$ ar I. glandulifera $(45,6 \%)$. I. noli-tangere populiacijos pasižymejjo mažiausia genetine diferenciacija $(0,36)$. Abiejų invazinių rūšių atveju pagal PKSI žymeklius populiacijų iš Čekijos polimorfizmas buvo didesnis už populiacijų iš Lietuvos. Atlikus Mantelio testą, abiejų žymeklių duomenimis, kiekvienai sprigių rūšiai nustatyta reikšminga koreliacija tarp populiacijų geografinių ir genetinių atstumų. Populiacijos iš Čekijos Respublikos, lyginant su Lietuvos populiacijomis, buvo didesnès, jų augavietès ịsikūrusios keliais šimtais metrų aukščiau jūros lygio, vidutinė metinė temperatūra buvo keliais laipsniais aukštesnè, vidutinis metinis kritulių kiekis mažesnis. Polimorfizmas, nustatytas pagal dviejų tipų DNR žymeklius, gali turèti nevienodą įtaką sprigių genties populiacijų gyvybingumui. Atskiriant vietines ir invazines sprigių rūšis, PKSI žymekliai buvo vertingesni už APPD žymeklius.

Reikšminiai žodžiai: Balsaminaceae, invazija, įvairovè, svetimkraštės rūšys, žymekliai. 